us. It refuses to use new lines of research offered by embryology and comparative morphology, and except in the accumulation of more material and some refinement in details it is hardly less but rather more of a book and skeleton study than it was fifty years ago, or even to Linnaeus himself. The earnest worker in other fields, and indeed present popular opinion can hardly be blamed for considering a good deal of it, and especially wrangling over nomenclature, as of a very amateurish sort, employing the faculties of the postage stamp collector rather than those of the naturalist.

To sum up: I do not believe in and do not teach the nomenclature of the Madison Congress, because I do not believe it can possibly prevail. It violates the psychological principles of the use of language, it is not sanctioned by the leading authority of the systematic world, past nor present, and its advocates give us no guarantee that they can produce works on North American botany of greater authority than those already in existence; it is impossible to secure the cooperation of the foreign botanists; it overturns much that was sufficiently stable, to replace it by a new system which has not the element of stability, since it will not be able to induce future botanists to use it.-W. F. GANONG.

\title{
Dr. Robinson and homonyms.
}

In the preceding number of the GAZETTE Dr. B. L. Robinson has presented another of his fatal objections to the principles of nomenclature adopted by the Botanical Club of the American Association-namely, the principle of the rejection of homonyms as applied to binominals. In support of this objection he cites not a case known to science, but a wholly suppositious one, the occurrence of which is a matter of almost ridiculous improbability. It should be answer enough that this is a purely hypothetical objection, especially if we are to be guided by Dr. Robinson's previous utterance ${ }^{1}$ that principles of nomenclature should not be laid on theoretical grounds. There probably will never occur a more glaring case of unscientific "lumping" of genera than that indulged in by Dr. Otto Kuntze when he united Bigelovia, Solidago, and Aplopappus with Aster, and yet even this lamentable piece of patchwork has not produced the chaotic results por-

\footnotetext{
1 Recommendations regarding the nomenclature of systematic botany, p. $\mathbf{I}$. (May, 1895).
} 
trayed by Dr. Robinson. The Botanical Club principles are explicit in this matter of homonyms, and the disposal of real cases, if any occur, presents no uncertainty and no difficulty to one who first reads the rule and then practices accordingly. Before discussing the practical validity of this objection we may at least ask that some actual cases be cited, and that the objection be not based solely on the alleged possibility of a preposterous publication on the part of some irresponsible botanist.

To illustrate the object and working of the rejection of homonyms as applied to binomials the following example will suffice. There is in the western United States a species of rush, closely related to Funcus nodosus and by some authors considered only a variety of it, but undoubtedly a good species and first treated as such in the year I86I under the name Funcus megacephalus Wood. Now according to the Botanical Club rules this name is not tenable because $\mathrm{Mr}$. M. A. Curtis as early as I 834 described under the same name, Funcus megacephalus, another rush which has been commonly known as Funcus scirpoides echinatus. According to Dr. Robinson's ideas, however, the name Funcus megacephalus Wood is entirely tenable, since Funcus megacephalus of Curtis was long since relegated to synonymy. This disposition appears at first sight to be satisfactory, but we may go a little further. A careful study of the group has shown that the variety echinatus is a valid species distinct from $\mathcal{F}$. scirpoides and that it must stand under the name funcus megacephalus Curtis. This would necessitate a change also in the name Funcus megacephalus Wood, since two species could not have the same name. According to Dr. Robinson, therefore, future critical work on this group, would entail a change not only in the name of the plant under examination but also in that of still another species having no relationship whatever with the first. According to the Association rules the name Funcus megacephalus Wood being untenable from the start would at once be changed and could in no way be affected subsequently by critical work on Funcus scirpoides and its varieties. The answer to the question which of these practices contributes to stability is evident.

In the last paragraph of his remarks Dr. Robinson introduces a depreciatory allusion to the botanists who attended the Madison meeting of the American Association, both as 
to their number and their standing.

This is a dangerous position, to say the least, - to challenge a public discussion of the relative scientific merits of prominent botanists. Consideration of such a question is in my opinion better left to each botanist for his personal and individual judgment. I must decline, therefore, to accept this tempting invitation, and content myself by yiving a list, from memory, of some of the botanists present at the Madison meeting:

J. C. Arthur,

Charles R. Barnes,

Charles E. Bessey,

N. L. Britton,

Mrs. E. G. Britton,

Douglas H. Campbell,
J. M. Coulter,

Frederick V. Coville,

E. L. Greene,

Byron D. Halsted,

A. S. Hitchcock,

Arthur Hollick,
W. A. Kellerman,

Conway MacMillan,

B. L Robinson,

W. T. Swingle,

Edwin B. Uline,

L. M. Underwood.

To these should be added the names of Henry H. Rusby, William Trelease, and Lester F. Ward, who although not present, voiced their approval as members of the nomenclature committee. Other professional botanists, whose names I do not at the moment recall, making the number of at least thirty, were present, besides the amateur botanists who customarily attend the meetings-altogether probably a larger and more broadly representative group of professional botanists than has ever attended a meeting of the American Association.

In his closing sentence Dr. Robinson gives vent to a statement as unfair in its implication as it is unwarranted in its assumption, to the effect that I have sought to decry any adverse criticism of the Association principles. What I did call attention to, and what I wish to point out again more plainly than before is that Dr. Robinson ignored the Association principles as long as possible, declined to discuss them at the times set for their discussion, and then after their final adoption conducted a "confidential" correspondence directed secretly against the reform. I doubt whether any committee could have given to nomenclatural principles more careful, deliberate, and judicial consideration than did the committee which prepared this code, and I repeat that Dr. Robinson's course, to say the least, seems to me wholly unjustifiable, assuming that he is working for the progress of systematic botany.-Frederick V. COVILle. 


\section{$2 \mathrm{BHL}$ Biodiversity Heritage Library}

Coville, Frederick V. 1895. "Dr. Robinson and Homonyms." Botanical gazette 20(7), 320-322. https://doi.org/10.1086/327214.

View This Item Online: https://www.biodiversitylibrary.org/item/88066

DOI: https://doi.org/10.1086/327214

Permalink: https://www.biodiversitylibrary.org/partpdf/222500

\section{Holding Institution}

Missouri Botanical Garden, Peter H. Raven Library

\section{Sponsored by}

Missouri Botanical Garden

\section{Copyright \& Reuse}

Copyright Status: Public domain. The BHL considers that this work is no longer under copyright protection.

This document was created from content at the Biodiversity Heritage Library, the world's largest open access digital library for biodiversity literature and archives. Visit BHL at https://www.biodiversitylibrary.org. 